\title{
Recenzje
}

DOI 10.35757/CIV.2014.16.09

\section{Gorset i skalpel}

\begin{abstract}
Agnieszka Gromkowska-Melosik: Kobieta epoki wiktoriańskiej. Tożsamość, ciało i medykalizacja, Oficyna Wydawnicza Impuls, Kraków 2013, ss. 191.
\end{abstract}

Jak twierdził Henry Maudsley, słynny brytyjski psychiatra schyłku XIX wieku: „Kształcenie, które wymaga skierowania energii na rozwój mózgu, uniemożliwia kobiecie prawidłowy rozwój biologiczny, w tym przede wszystkim rozwinięcie jej organów

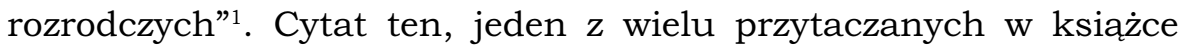
Agnieszki Gromkowskiej-Melosik fragmentów literatury medycznej epoki wiktoriańskiej, czasów, które autorka uczyniła podstawa swych analiz, daje pewne wyobrażenie o tematyce całości recenzowanej pracy. Agnieszka Gromkowska-Melosik, profesor Uniwersytetu im. Adama Mickiewicza na Wydziale Studiów Edukacyjnych w Poznaniu, wprawdzie publikowała już prace $z$ zakresu gender studies, lecz jej najnowsza książka także wpisuje się w ten interdyscyplinarny nurt badań nad płcia kulturową. Tym razem jednak zdecydowała się pokazać, w jaki sposób model wiktoriańskiej

1 H. Maudsley: Sex in Mind and in Education, New York 1884, cyt. za: A. Gromkowska-Melosik: Kobieta epoki wiktoriańskiej. Tożsamość, ciało i medykalizacja, Oficyna Wydawnicza Impuls, Kraków 2013, s. 147. 
kobiecości był kształtowany przez dziewiętnastowieczną naukę, a zwłaszcza przez ówczesną medycynę.

Kobieta epoki wiktoriańskiej... jest pierwsza na polskim rynku wydawniczym publikacja poświęcona wyłącznie dyskursom o dziewiętnastowiecznej kobiecości. Autorka skorzystała z licznych tekstów źródłowych, a przede wszystkim $z$ anglojęzycznej literatury przedmiotu. W końcu zarówno medycyna, edukacja, jak i moda epoki wiktoriańskiej doczekały się już wielu, głównie brytyjskich i amerykańskich, opracowań. Kobieta epoki wiktoriańskiej... nie jest więc praca w pełni nowatorska, a postawiona $\mathrm{w}$ niej teza - o medykalizacji życia dziewiętnastowiecznych kobiet - nie jest też odkrywcza. Książka Agnieszki Gromkowskiej-Melosik może jednak zainteresować zarówno historyków badajacych epokę wiktoriańska, socjologów medycyny, jak i pasjonatów gender studies zwłaszcza jako źródło barwnych przykładów, ilustrujących wybrane zjawiska tej epoki. Niewatpliwa zaleta publikacji jest przetłumaczenie na język polski licznych fragmentów tekstów źródłowych. Niestety, po lekturze tej pracy nie należy spodziewać się wiele więcej.

Agnieszka Gromkowska-Melosik zaczyna książkę od szeregu zastrzeżeń. Podkreśla, że Kobieta epoki wiktoriańskiej... nie opisuje życia kobiet tej epoki w sposób wyczerpujący. Autorka koncentruje się na wąskim wycinku rzeczywistości: wyłącznie na medykalizacji życia kobiet $z$ wyższych klas społecznych. Jej praca nie jest drobiazgową rozprawą historyczna, ale raczej próba interpretacji wybranego fragmentu wiktoriańskiej kultury. Analizujac teksty dziewiętnastowiecznych medyków i moralistów, autorka używa terminologii świadomie zaczerpniętej od Michela Foucault. Stara się pokazać, w jaki sposób wiktoriańska medycyna służyła do dyscyplinowania jednostek, a stan ówczesnej władzy/wiedzy kształtował ich tożsamość. Jej praca wydaje się więc rodzajem uzupełnienia diagnozy, która wiele lat temu postawił francuski historyk i filozof. Niestety, nie jest to uzupełnienie kompletne, $z$ czego wszakże autorka zdaje sobie sprawę. 
Omawiane dzieło odmalowuje obraz badanej epoki niezwykle jednostronnie. Autorka przytacza szereg wymagań i zaleceń stawianych dziewiętnastowiecznym kobietom, nie konfrontując ich jednak $z$ reakcjami ówczesnych kobiet na takie wymagania. Gdyby wzbogacić pracę Agnieszki Gromkowskiej-Melosik o analizę wybranych biografii kobiet tej epoki czy sięgnąc do ich pamiętników, wynik przeprowadzonych badań $z$ pewnościa byłby o wiele bardziej przekonujący. Ta wada książki widoczna jest jeszcze wyraźniej, gdy porówna się Kobietę epoki wiktoriańskiej... do innej wydanej w 2014 roku pracy o zbliżonej tematyce, a mianowicie do Płci powstania warszawskiego Weroniki Grzebalskiej. Autorka tej publikacji zrekonstruowała „powstańczy dyskurs kobiecości”, analizujac liczne historyczne dokumenty, odezwy do narodu, symbole narodowe czy nawet wiersze i piosenki. Wyłaniajacy się $z$ tych źródeł historycznych model kobiecości zderzyła zarazem ze świadectwami kobiet bioracych udział w powstaniu. Tak uzyskany obraz wydał mi się o wiele pełniejszy niż rekonstrukcja Agnieszki Gromkowskiej-Melosik. Autorka Kobiety epoki wiktoriańskiej... nie próbuje znaleźć odpowiedzi na pytanie, w jakim stopniu obowiązujacy dyskurs medyczny faktycznie dyscyplinował codzienne życie większości kobiet, jej analiza zatrzymuje się na rekonstrukcji samego dyskursu.

Autorka traktuje epokę wiktoriańska jako międzynarodowy fenomen cywilizacyjny. Nie ogranicza się jedynie do analizy życia brytyjskich kobiet za panowania królowej Wiktorii. Sięga także do źródeł francuskich czy amerykańskich. Co więcej, książka nie jest oparta wyłącznie na studiowaniu utworów pisanych (dziewiętnastowiecznych rozpraw naukowych, poradników, moralitetów) - autorka interpretuje w niej również wybrane dzieła malarskie $z$ epoki. Niemniej tym analizom dziewiętnastowiecznych obrazów można zarzucić pewne nadinterpretacje, choć przyznać trzeba, że jest to dziedzina, którą trudno jednoznacznie ocenić.

Inną wadą książki sa powtórzenia, których Gromkowska-Melosik nie zdołała uniknać. W końcu wiktoriańskie przekonania na temat 
kobiecej urody, inteligencji czy zdrowia wynikały często $z$ tych samych przesłanek. Poszczególne wątki dziewiętnastowiecznego dyskursu kobiecości powracaja więc w ksiażce wiele razy. Co więcej, kiedy autorka przechodzi od rekonstrukcji danych poglądów $z$ epoki do próby ich wyjaśnienia, jej argumentacja nie zawsze jest przekonująca. Na przykład, gdy zastanawia się nad przyczynami restrykcyjnej kontroli dziewiętnastowiecznej seksualności, w dyscyplinowaniu mężczyzn dopatruje się ukrytego lęku przed utratą władzy klasowej (nad klasami niższymi) i płciowej (nad kobietami). Takie wyjaśnianie ludzkich zachowań zideologizowanymi podświadomymi motywacjami $z$ pewnością nie przemówi do części czytelników.

Jednym $z$ centralnych pojęć recenzowanej pracy jest medykalizacja. Pojęcie to, jak podaje autorka za amerykańskim socjologiem medycyny, Peterem Conradem, oznacza „proces, w trakcie którego wcześniej uważane za niemedyczne aspekty życia zaczynaja być postrzegane w terminach medycznych, zwykle jako zaburzenia lub choroby"2. W pracy Agnieszki Gromkowskiej-Melosik próżno szukać pogłębionych rozważań teoretycznych nad pojęciem medykalizacji, autorka stara się raczej zilustrować samo zjawisko licznymi przykładami. Zauważa, że w XIX wieku przybierało ono często formę odchodzenia od religijnych interpretacji ludzkich zachowań w stronę interpretacji medycznych. I tak, to, co wcześniej określano mianem opętania kobiety przez szatana, teraz zaczęto traktować jako objawy histerii lub nimfomanii. Proces ten przyspieszył wraz $z$ rozwojem nauk przyrodniczych. Przekonanie o biologicznie zdeterminowanej naturze przedstawicielek płci pięknej, których cała cielesność i duchowość jest podporządkowana dążeniu do reprodukcji, otworzyło pole do powstawania nowych medycznych praktyk, dlatego też, zdaniem autorki, wiktoriańskie kobiety podlegały medykalizacji w większym stopniu niż mężczyźni.

Książka jest podzielona na sześć rozdziałów, a każdy $z$ nich poświęcono innemu aspektowi wiktoriańskiej kobiecości. W rozdziale pierwszym autorka zastanawia się nad rolą kobiety $\mathrm{w}$ dzie-

2 A. Gromkowska-Melosik: Kobieta epoki wiktoriańskiej..., s. 17. 
więtnastowiecznej medycynie. Rozdział drugi skupia się na medykalizacji macierzyństwa. Trzeci koncentruje się na problemach urody i seksualności kobiet. Czwarty analizuje wiktoriańskie przekonania naukowe na temat ich umysłowości. Piąty omawia histerię i blednicę - kobiece choroby epoki wiktoriańskiej. Rozdział szósty stanowi krótkie podsumowanie całości.

Za jeden $z$ symboli epoki wiktoriańskiej można uznać gorset. Autorka relacjonuje dziewiętnastowieczne spory medyczne, dotyczące tej części garderoby. Większość ówczesnych lekarzy twierdziła, że $z$ powodu kruchych kości i słabych mięśni kobiety nie sa w stanie utrzymać prostych pleców o własnych siłach. Inni medycy obawiali się, że gorset osłabia kobieca zdolność do reprodukcji. Agnieszka Gromkowska-Melosik pokazuje, w jaki sposób wiktoriańska moda kształtowała tożsamość kobiet tej epoki. Niemniej gorsety, falbanki i koronki to tylko część narzędzi nadających pożądany kształt dziewiętnastowiecznej kobiecości. Ówczesna medycyna wyjątkowo często sięgała po skalpel. Rzućmy okiem na wybrane przykłady dziewiętnastowiecznej medykalizacji, które tak sprawnie autorka rekonstruuje.

Jedna $z$ nowych sfer działalności lekarskiej stało się prowadzenie ciąży, w końcu zawód położnika-mężczyzny pojawił się dopiero w tej epoce. Dziewiętnastowieczna medycyna cała odpowiedzialność za jakiekolwiek zaburzenia w czasie ciąży lub wady narodzonego już dziecka przypisywała kobietom. Aby ich uniknąć, należało wypełniać wskazania lekarza. I tak, w poradniku z 1837 roku możemy znaleźć następujące zalecenia dla ciężarnych kobiet: „[...] oblewanie zimna wodą lędźwi i bioder oraz zastosowanie prześcieradła umoczonego w zimnym occie i wodzie, perfekcyjna abstynencja i środki przeczyszczające co cztery godziny”. Ponadto, jak czytamy dalej, kobieta ciężarna „[...] przez jeden akt nieposłuszeństwa (swojemu lekarzowi) może zniszczyć jakąkolwiek nadzieję na sukces"3. W epoce wiktoriańskiej panie miały podstawy

3 T. Bull: Hints to Mothers, for the Management of Health During the Period of Pregnancy..., London 1837, cyt. za: A. Gromkowska-Melosik: Kobieta epoki wiktoriańskiej..., s. 40. 
do niepokoju. „W 1886 roku w paryskich szpitalach zmarła jedna czwarta rodzacych kobiet"4 - jak, za Adrienne Rich, podaje autorka. Jednocześnie jednak kobiety bały się bać, ponieważ ówczesna medycyna zgodnie głosiła, że wszelkie silne emocje w czasie ciąży doprowadza do uszkodzenia płodu. Uważano również, że wewnętrzne przeżycia kobiety karmiącej moga zepsuć jej mleko do tego stopnia, iż otruje własne dziecko.

Wśród wiktoriańskich uczonych dużą popularnością cieszyła się tzw. teoria zachowania energii. Uważano, że kobieta nie jest w stanie jednocześnie pełnić swoich funkcji rozrodczych i tracić siły na pracę umysłową. Energia może być skierowana albo do mózgu, albo do macicy, trzeciej możliwości nie ma. Jak pisał wówczas Edward Clark, profesor Harvard College: „Kobieta może się nauczyć wszystkiego, czego nauczy się mężczyzna, nie w tym tkwi problem [...] nie pozostanie to bez wpływu na jej zdrowie i nie uchroni jej to przed zachorowaniem na neuralgię, schorzenia macicy, histerię i inne zaburzenia układu nerwowego. [...] Cera kobiet od nauki blednie, szarzeje, włosy kołtunieja, pojawia się anemia i neuralgia, deformacje kręgosłupa, upławy, zaburzenia cyklu menstruacyjnego, bolesne miesiączkowanie, chroniczne lub ostre zapalenie jajników, w końcu wypadnięcie macicy"5. Poglądy natury medycznej wpływały więc na obowiąujący kobiety $z$ wyższych sfer kanon wykształcenia: dziewczęta uczono języków obcych, zaznajamiano je $z$ wybrana literatura, szydełkowaniem, uczono gry na fortepianie. Wiedza $z$ każdej $z$ tych sfer miała jednak pozostać na poziomie ogłady towarzyskiej. Niektórzy wiktoriańscy uczeni obawiali się wszakże, iż nawet taka edukacja może być dla kobiet niebezpieczna. „Wielu ginekologów i psychiatrów, uważało, że gra na fortepianie "nadmiernie stymuluje system nerwowy", dokonując "spustoszenia nerwów i organów reprodukcyjnych". Uważano,

\footnotetext{
4 A. Rich: Compulsory Heterosexuality and Lesbian Existence, w: H. Abelove, M.A. Barale, D.M. Halperin (red.): The Lesbian and Gay Studies Reader, New York - London 1993, cyt. za: A. Gromkowska-Melosik: Kobieta epoki wiktoriańskiej..., s. 41.

5 E.H. Clarke: Sex in Education...., Boston 1875, cyt. za: A. Gromkowska-Melosik: Kobieta epoki, wiktoriańskiej..., s. 144.
} 
że muzyka prowadzi do choroby przez "prowokowanie zmysłowości, wyobraźni i seksualności», może być także "źródłem neurastenicznego zmęczenia $z$ powodu intelektualnego nadwyrężenia»"б.

Przekonanie o tym, że zdolność do reprodukcji stanowi esencję kobiecości kształtowało dziewiętnastowieczne poglądy na temat zdrowia psychicznego i fizycznego kobiet. „W wydanym w 1889 roku raporcie ministerstwa zdrowia w Stanach Zjednoczonych napisano, że $51 \%$ operacji usunięcia jajników przeprowadzono $\mathrm{w}$ celu wyleczenia zaburzeń psychicznych u pacjentek"7. Macica uznawana była za centralny narząd w organizmie kobiety, wszelkie zaburzenia emocjonalne, niespotykane zachowania lub schorzenia fizyczne musiały więc mieć $z$ nią jakiś związek.

Agnieszka Gromkowska-Melosik zwraca uwage na niekonsekwencje $\mathrm{w}$ wiktoriańskim postrzeganiu natury kobiet. $Z$ jednej strony podkreślano, że takie cechy, jak delikatność, moralność, oziębłość seksualna czy wstydliwość, są naturalnie wpisane w kobieca psychikę i cielesność. $Z$ drugiej strony lekarze i moraliści wyrażali nieustannie obawy przed utrata owych naturalnych cech - jakby każda kobieta była o krok od popadnięcia w szaleństwo, zwłaszcza na tle seksualnym. W świecie wiktoriańskich poradników medycznych i moralitetów aż roi się od ukrytych pokus - w końcu nawet gra na fortepianie lub świeże powietrze moga wzbudzić w dziewczętach „niezdrowe pobudzenie” czy „grzeszne myśli”. Purytańska wstydliwość i mania czystości stwarzały kulturę obsesyjnie zainteresowana seksem. Kobieta epoki wiktoriańskiej jest „jednocześnie niewinna i potencjalnie zepsuta" 8 , jako jednostka niezdolna do samokontroli potrzebuje kontroli $z$ zewnattrz.

Wyjatkowo ciekawy przypadek, ze względu na jego odniesienia do współczesności, stanowiła omawiana w książce blednica (chlorosis), czyli anemia spowodowana niedożywieniem. Choroba ta bywa

\footnotetext{
6 J. Kennaway: The piano Plague. The Nineteenth-Century Medical Critique of Female Musical Education, „Gesnerus” 2011, t. 68, nr 1, cyt. za: A. Gromkowska-Melosik: Kobieta epoki wiktoriańskiej..., s. 143.

7 A. Gromkowska-Melosik: Kobieta epoki wiktoriańskiej..., s. 113.

8 Ibidem, s. 97.
} 
uznawana za dziewiętnastowieczny odpowiednik współczesnej anoreksji. Agnieszka Gromkowska-Melosik zauważa, że takie choroby, jak histeria, blednica czy współczesna anoreksja, stanowia swego rodzaju parodie obowiąującego modelu kobiecości i sa wyrazem (nieudanego) buntu wobec oczekiwań społecznych, który objawia się właśnie przez ich przerysowanie. Kobieta histeryczna jest zbyt emocjonalna, pozbawiona samokontroli, $z$ kolei odmawiajaca jedzenia anorektyczka realizuje ideał kobiecej szczupłości i zwiewności, aż do anihilacji samej siebie. Argumentem na rzecz kulturowej interpretacji tych chorób może być fakt, że zmiany w obyczajowości wyraźnie wpływały na częstotliwość ich występowania. Agnieszka Gromkowska-Melosik jednak skupia się w książce wyłącznie na dziewiętnastym wieku, a kwestia współczesnej anoreksji jest w niej jedynie wspomniana.

Mimo słabych stron Kobieta epoki wiktoriańskiej... pozostaje źródłem wielu fascynujacych przykładów i może być ciekawa pozycja dla wszystkich zainteresowanych historia płci oraz zjawiskiem medykalizacji. Czytając fragmenty dziewiętnastowiecznych poradników medycznych, nie sposób także patrzeć na współczesną naukę bez odrobiny niepokoju.

Emilia Kaczmarek

$\overline{\text { Emilia Kaczmarek - doktorantka w Zakładzie Etyki Instytutu Filozofii Uniwersytetu War- }}$ szawskiego. 